\title{
MEMBANGUN KEPRIBADIAN SANTRI MELALUI INTEGRASI PENDIDIKAN DI PESANTREN TERPADU DARU ULIL ALBAB KELUTAN NGRONGGOT NGANJUK
}

\author{
Abd. Qadir \& Badrus \\ Program Pascasarjana Institute Agama Islam Tribakti Kediri
}

\begin{abstract}
Abstrak
Kepribadian santri yang kokoh harus terus diperkuat dengan berbagai strategi yang handal. Hal ini penting untuk membentengi pengaruh budaya dari luar, agar para santri memiliki kepribadian yang tangguh dalam mewujudkan kehidupan mendatang yang selamat dan sejahtera. Untuk membentuk kepribadian santri yang kuat diperlukan model pendidikan yang dapat dijamin keberhasilannya. Salah satunya adalah model pendidikan yang integrative. Namun bagaimana secara operasional model pendidikan integrative ini membentuk kepribadian santri.

Penelitian ini bertujuan untuk menganalisis bagaimana pelaksanaan integrasi pendidikan di pesantren Daru Ulil Albab, apa target dari praktik Integrasi pendidikan ini, dan bagaimana upaya pesantren Daru Ulil Albab dalam mencapai target tersebut.

Jenis penelitian ini adalah kualitatif dengan pendekatan grounded teori (Grounded Theory Approach) yaitu suatu metode penelitian kualitatif. Sementara metode penggalian datanya menggunakan metode observasi, wawancara dan dokumentasi. Analisis datanya menggunakan tiga tahap yakni reduksi data (reduction), display data (display), dan penarikan kesimpulan (conclusion drawing) dari Miles dan Hubberman.

Kesimpulan dari penelitian ini adalah; integrasi pendidikan di pesantren ini dengan cara memadukan lima unsur pendidikan. Pertama keterpaduan sarana prasarana. Kedua. keterpaduan kelembagaan. Ketiga, keterpaduan kurikulum. Keempat, keterpaduan manajemen. Kelima, Keterpaduan tradisi. Sedang target yang ingin di capai adalah, "menjadi pribadi-pribadi yang baik badannya, baik akalnya, dan baik hatinya (sehat hahir dan bathin), memiliki sistem manajerial yang baik solid dan kuat, memiliki sarana pendidikan yang memadahi dan lembaga unit yang variatif. Sedang upaya yang dilakukan untuk mencapai target adalah; optimalisasi kegiatan, optimalisasi pengeloaan dan pengawasan, pengembangan kelembagaan, dan pengembangan sarana prasarana.
\end{abstract}

Kata Kunci: Kepribadian Santri, Integrasi Pendidikan

\section{A. Kontek Penelitian}

Kepribadian santri yang kokoh harus terus diperkuat dengan berbagai strategi yang handal. Hal ini penting untuk membentengi pengaruh budaya dari luar, agar para santri memiliki kepribadian yang tangguh dalam mewujudkan kehidupan mendatang. Pesan dari undangundang system pendidikan nasional menyatakan bahwa, penyelenggaraan pendidikan nasional berfungsi untuk mengembangkan kemampuan dan membentuk watak serta peradaban bangsa yang bermartabat dalam rangka mencerdaskan kehidupan bangsa. ${ }^{1}$.

Masalah besar yang muncul dalam kehidupan berbangsa setidaknya ada lima, yaitu merosotnya kewibawaan Negara, melemahnya sendi perekonomian nasional, merebaknya intoleransi dan krisis kepribadian bangsa, kebebasan berpendapat yang kebablasan, dan masalah etos kerja dan budaya semakin menurun. ${ }^{2}$

1 Sistem Pendidikan Nasional (sisdiknas), Nuansa Aulia (Revisi), Bandung, 2010, hal. 4

2 Parliament Magazine, 3 Masalah besar Bangsa Indo- 
Di sisi lain untuk mengatasi masalah besar di atas berbagai upaya telah dilakukan pemerintah, termasuk mempopulerkan pendidikan karakter. Namun sampai saat ini program itu belum dapat dikatakan berhasil. Indikasinya, yaitu masih bermunculan karakter negative di masyarakat, seperti ketidak disiplinan, budaya jam karet, suka melanggar peraturan, korupsi yang meluas serta penyalahgunaan wewenang dan pelanggaran hokum yang terkadang dianggap sebagai hal biasa. $^{3}$

Sekalipun demikian, pendidikan karakter harus terus dikembangkan, hingga nanti bangsa ini menjadi bangsa yang memiliki karakter tinggi demi kejayaan Negara. Salah satu lembaga pendidikan yang terus berupaya membangun karakter (baca kepribadian) adalah pesantren terpadu Daru Ulil Albab Kelutan Ngronggot Nganjuk.

Pesantren Daru Ulil Albab merupakan pesantren di pinggiran Kali Brantas, yang sejak berdirinya memiliki orientasi membangun institusi pendidikan terpadu dari berberapa komponen dan unit-unit pendidikan yang ada. Bahkan bentukan out put dari pondok ini diarahkan mejadi lulusan yang ahli agama dan ahli teknologi sekaligus. ${ }^{4}$

Atas dasar itu penulis tertarik untuk mengadakan penelitian di pesantren terpadu Daru Ulil Albab Kelutan Ngronggot Nganjuk, karena pesantren ini memiliki keunikan dalam menyelenggarakan pendidikan, yaitu model pendidikan pesantren berbentuk integral dan berjenjang, dengan mengggabungkan pendidikan formal, informal dan nonformal dalam satu manajemen.

Konsentrasi penelitian diarahkan pada seputar konsep intergasi pendidikan, target dan tujuan dari integrasi pendidikan, pelaksanaan dan pengawasan kegiatan integrasi pendidikan. Dengan harapan, hasil penelitian ini akan

nesia dan Revolosi Mental (online) https://wartainfrastrukturindonesia.wordpress. Diakses, 20 Juni 2016.

3 Indonews.com. Ratih Keswara. Pendidikan Karakter, Solusi kikis masalah bangsa. (online) http://nasional. indonews.com/read/820691/...diakses 18 Juni 2016

4 Wawancara dengan Pembina P. Kharisudin aqib, pembinan PP Daru Ulil albab, 15 Mei 2017. berguna bagi peneliti, lembaga sasaran penelitian, praktisi pendidikan dan dunia pendidikan pada umumnya.

\section{B. Fokus Penelitian}

Fokus penelitian ini meliputi; 1) bagaimana pelaksanaan integrasi pendidikan di pesantren Daru Ulil Albab Kelutan, 2) Apa target praktik Integrasi Pendidikan di pesantren Daru Ulil Albab, dan 3) bagaimana upaya pesantren Daru Ulil Alab dalam mewujudkan target.

\section{KAJIAN PUSTAKA}

\section{Teori Kepribadian}

Konsep kepribadian sangat bervariasi menurut para ahli. Roucek dan Warren, menyatakan bahwa kepribadian adalah organisasi faktor-faktor biologis, psikologis, serta sosiologis yang mendasari perilaku individu. Sementara Koentjaraningrat, di dalam bukunya yang berjudul "Pengantar Antropologi I", menyatakan bahwa kepribadian tersusun dari unsur-unsur akal serta juga jiwa yang menentukan tingkah laku atau juga tindakan seseorang. Sedangkan Yinger, memberikan penjelasan bahwa kepribadian adalah keseluruhan dari perilaku seseorang dengan sistem kecenderungan tertentu yang berinteraksi atau berhubungan dengan serangkaian situasi. Jadi, bisa disimpulkan bahwa kepribadian adalah suatu perpaduan yang utuh antara sifat, sikap, pola pikir, emosi, serta juga nilai-nilai yang mempengaruhi individu tersebut agar berbuat sesuatu yang benar sesuai dengan lingkungannya.

Sementara teori kepribadian yang dikenal dewasa ini tiga teori utama. Pertama, teori kepribadian Psikoanalisa (Freud). Yang menyatakan bahwa Id adalah komponen kepribadian yang berisi impuls agresif dan libinal, dimana sistem kerjanya dengan prinsip kesenangan "pleasure principle". Sedangkan Ego adalah bagian kepribadian yang bertugas sebagai pelaksana, sistem kerjanya pada dunia luar untuk menilai realita dan berhubungan dengan dunia dalam untuk mengatur dorongandorongan id agar tidak melanggar nilai- 
nilai superego. Superego adalah bagian moral dari kepribadian manusia, karena ia merupakan filter dari sensor baik.

Kedua, teori kepribadian Behaviorisme (Skinner), yang menyatakan bahwa faktorfaktor penentu tingkah laku tersebut berasal dari stimulus-stimulus eksternal. Skinner berpendapat bahwa tingkah laku manusia tidak digerakkan oleh agen-agen internal yang disebut naluri, melainkan ditentukan oleh kekuatan-kekuatan eksternal. Freud dengan psikoanalisanya percaya bahwa misteri manusia akan bisa diungkap seluruhnya melalui upaya-upaya ilmiah, karena pada dasarnya tubuh manusia mengikuti hukumhukum fisika, Skinner dan segenap behavioris memiliki anggapan yang sama dengan Freud. dan ketiga, teori kepribadian Humanistik (Maslow) $^{5}$. Menyatkan bahwa psikolog yang berorientasi humanistic mempunyai satu tujuan, mereka ini memanusiakan psikologi. Mereka ingin membuat pskologi sebagai studi tentang "apa makna hidup sebagai seorang manusia". Mereka berasal dari berbagai latar belakang dan keyakinan yang beragam.

\section{Faktor-faktor Yang Mempengaruhi Kepribadian}

Pada tiap-tiap orang pasti mempunyai warisan biologis yang berbeda dengan orang yang lainnya juga. Warisan biologis tersebut dapat berupa bentuk fisik yang berbeda antara satu dengan yang lain, bahkan juga pada anak kembar sekalipun.

Faktor Geografis dan Kebudayaan Khusus

Letak geografis yang berbeda tersebut akan menghasilkan suatu jenis kebudayaan yang akan berbeda pula. Misalnya masyarakat pesisir akan menghasilkan kebudayaan nelayan, dan masyarakat pedesaan akan menghasilkan kebudayaan petani, serta juga kebudayaan masyarakat kota.

5 Dian Amalia Sunaryo, Konsep-konsep kepribadian. (on line) http://amalia-sunaryo.blogspot.co.id/2013/04/ konsep-kepribadian-dan-pola-perilaku.html. diakses 28/09/2016

\section{Faktor Pengalaman Kelompok}

Selama kehidupan seseorang, pasti terdapat kelompok-kelompok tertentu yang diserap adanya gagasan-gagasan serta juga norma-normanya oleh seseorang. Kelompok keluarga merupakan kelompok pertama yang akan dilalui oleh suatu individu dan juga mungkin yang mempunyai peranan paling penting bagi pembentukan kepribadian seseorang.

\section{Faktor Pengalaman Unik}

Dua orang yang hidup di lingkungan yang sama, belum tentu akan mempunyai kepribadian yang sama, bahkan pada orang yang lahir kembar sekalipun. Hal itu disebabkan karena adanya pengalaman yang pernah didapatkan oleh masing-masing individu yang selalu bersifat unik serta juga tidak ada seorangpun yang menyamainya,

\section{Kepribadian Dalam Pandangan Islam}

Secara umum kepribadian seseorang terbentuk karena dipengaruhi oleh dua hal. Pertama, Fitrah bawaan sejak lahir dari warisan genetika orang tuanya. Kedua, melalui proses panjang riwayat hidupnya ${ }^{6}$. 1) Fitrah bawaan sejak lahir dari warisan genetika orang tuanya. Jika orang tuanya berakhlaq baik, maka anaknya akan berakhlaq baik, jika orang tuanya memiliki sifat-sifat yang buruk, maka sifat-sifat tersebut akan terdapat pula pada anaknya, sehingga terbentuklah kepribadian. 2) Melalui proses panjang riwayat hidupnya. Proses internalisasi nilai pengetahuan dan pengalaman dalam dirinya. Dalam perspektif ini maka keyakinan agama yang ia terima dari pengetahuan maupun dari pengalaman masuk dalam struktur kepribadian seseorang. Anak yang dididik dengan nilai-nilai keislaman akan terbiasa menjalankan ibadah, dan patuh pada kewajiban-kewajiban seorang muslim.

6 Salma Siti Sholiha, Kepribadian dalam pandangan Islam, (on line)http://salmafinzana.blogspot. co.id/2013/12/kepribadian-dalam-pandangan islam. $\underline{\text { html }} 14$ Desember 2013, diakses 28 Sept 016 


\section{Tahap-tahap Pembentukan kepribadian}

Proses sosialisasi dan internalisasi tersebut terjadi akan melalui beberapa tahapantahapan sebagai berikut ${ }^{7}$.

\section{a. Tahap Persiapan (Preparatory Stage).}

Pada saat seseorang dilahirkan, dia sudah siap mengenal dunia sosialnya, termasuk siap memahami dirinya sendiri. Pengenalan diri dan lingkungan terjadi berkat kemampuan berpikir. Kemampuan berpikir memungkinkan seorang bayi meniru beberapa hal yang dia lihat atau dia dengar, walaupun masih belum sempurna. Kemudian semakin berkembang, sehingga pada tahap berikutnya seorang anak mampu meniru hampir semua perilaku orang dewasa yang ada di dekatnya.

\section{b. Tahap Meniru (Play Stage).}

Pada tahap ini seorang anak dapat meniru berbagai tingkah secara sempurna. Anak perempuan berusia $3-5$ tahun mampu meniru tingkah laku wanita dewasa dalam bentuk permainan 'pasar-pasaran', sedangkan anak laki-laki dalam usia sama biasanya suka bermain 'perang-perangan'.

\section{c. Tahap Siap Bertindak (Game Stage).}

Memasuki tahap ini, seorang anak mulai mengurangi proses peniruan. Mereka secara langsung mulai berani memainkan peranan dirinya dengan penuh kesadaran. Kemampuannya dalam menempatkan diri pada posisi orang lain pun meningkat.

\section{d. Tahap Penerimaan Norma Kolektif (Generalized Other)}

Pada tahapinianak telah memasukijenjang orang dewasa. Selain dapat menempatkan diri sebagai orang lain, juga harus dapat menempatkan diri sebagai anggota masyarakat luas. Untuk ini diperlukan sikap tenggang rasa dengan sesama warga masyarakat.

7 Tahap-tahap Pembentukan Kepribadian, (on line) http://www.ilmusocial.com/tahap-tahap-pembentukankepribadian/ 21 Januari 2015, diakses 27/09/2016

\section{Integrasi Pendidikan}

Ada dua makna Integrasi dalam tipologi. Pertama, bahwa integrasi mengandung makna implisit reintegrasi, yaitu menyatukan kembali pendidikan sekolah, rumah, dan masyarakat setelah ketiganya terpisah. Kedua, integrasi mengandung makna unity, yaitu bahwa pendidikan sekolah, rumah, dan masyarakat merupakan kesatuan primordial (paling dasar).

Jadi, integrasi pendidikan yang dimaksud adalah suatu upaya penyatuan, proses pengubahan sikap dan tata laku seseorang atau kelompok dalam usaha mendewasakan manusia melalui upaya pengajaran dan pelatihan dalam lingkungan keluarga, sekolah dan masyarakat untuk mencapai tujuan pendidikan.

\section{Konsep Dasar Integrasi Pendidikan}

Dengan mengacu pada undang-undang RI No. 20 tahun 2003 bab III pasal 1 ayat 3 dan pasal 4 butir 6 , maka dapat dipahami bahwa konsep penyelenggaraan pendidikan yang sesuai dengan amanat undang undang tersebut adalah penyelenggaraan pendidikan yang terpadu (integreted) sebagai satu kesatuan sistemik, memberdayakan semua komponen masyaakat, terbuka dan multi makna, agar peserta didik bisa menjadi manusia yang beriman dan bertakwa kepada Tuhan Yang Maha Esa, berakhlak mulia, sehat, berilmu, cakap, kreatif, mandiri, dan menjadi warga Negara yang demokratis serta bertanggung jawab. Untuk itu dibutuhkan adanya teori pendidikan yang bisa menyentuh seluruh aspek diatas secara komperhenship.

\section{Pesantren Terpadu}

Pada dasarnya pesantren terpadu merupakan penyelenggara pendidikan yang komprehensif atau pendidikan holistic, yaitu pendidikan yang mengintegrasikan ilmu pengetahuan, budi pekerti, kreativitas, dan inovasi dalam suatu kesatuan. Pendidikan komprehensif adalah pendidikan yang mampu mengeksplorasi seluruh potensi peserta didik. 


\section{Konsep Pesantren Terpadu}

Terpadu merupakan keterkaitan beberapa system dalam pendidikan yang dapat diterapkan, mulai dari visi-misi, kurikulum, manajemen dan jaringan pendidikan yang dapat mengembangkan dan memajukan lembaga pendidikan Islam secara baik ${ }^{8}$.

Konsep terpadu menurut Rachmat Syarifudin (2007). Pertama, keterpaduan antara orang tua dan guru dalam membimbing anaknya. Kedua, keterpaduan kurikulum Ketiga, keterpaduan konsep pendidikan. Ada sinergi antara stakeholder yang terkait dengan pendidikan tersebut. ${ }^{9}$

Tujuan pendidikan pondok pesantren pada mulanya tidak dirumuskan secara jelas. Hal ini karena dapat dimaklumi, bahwa pondok pesantren sejak awal berdirinya tidak membutuhkan legalitas secara formal. Dalam bentuk yang sangat sederhana tujuan itu dapat dirumuskan secara garis besar bahwa pondok pesantren merupakan lembaga pendidikan Islam yang berorientasi untuk mendidik para santrinya agar tafaqqauh fiddin (memegang teguh ajaran Islam). Di sisi lain, tujuan pendidikan pondok pesantren secara spesifik adalah disesuaikan dan diselaraskan dengan penguasaan para pemegang pondok pesantren tersebut dalam suatu konsentrasi ilmu tertentu.

\section{METODE PENELITIAN}

Jenis penelitian yang digunakan dalam penelitian ini adalah kualitatif dengan pendekatan grounded teori (Grounded Theory Approach). yaitu suatu metode penelitian kualitatif yang menggunakan sejumlah prosedur sistematis guna mengembangkan teori dari kancah.

Alasan penulis memilih pendekatan ini karena sesuai dengan sifat penelitian yang akan dilakukan, yaitu mengidentifikasi permasalahan, mengidentifikasi hal-hal

8 Deding Sudarso "Lembaga Pendidikan Islam Terpadu" (on line) http://dedingsudarso.blogspot.co.id/2010/04/ lembaga-pendidikan-islam-terpadu.html diakses 20 April 2016

9 (Dikutip Rachmat Syarifudin, "JSIT Memberdayakan Sekolah-Sekolah Islam" (on line) copyright@2007 www. republika.com). diakses 20 April 2016 yang melatarbelakangi munculnya masalah dimaksud dan menjadi fokus penelitian.

\section{Lokasi Penelitian}

Penelitian ini dilakukan di Pesantren Terpadu Daru Ulil Albab yang lokasi di RT/RW 06/01 dusun Kelutan Desa Kelutan Kecamatan Ngronggot Kabupaten Nganjuk. Secara geografis pesantren ini berada di sebelah barat Kabupaten Kediri, tepatnya \pm 700 meter sebelah selatan Jembatan Kelutan-Papar dengan, desa terdekat dari pesantren ini adalah sebelah utara desa Banjarsari sebelah barat desa Cengkok sebelah selatan desa Juwet, dan sebelah timur desa Papar.

\section{Prosedur Pengumpulan data}

Untuk memperoleh data penelitian diguanakan metode observasi, wawancara dan dokumentasi. Observasi dilakukan untuk mencari gambaran deskripsi secara umum dan luas yang mencerminkan situasi dan kondisi riil Metode ini digunakan untuk mengetahui kekuatan, kelemahan, peluang, dan pondok pesantren. Selain itu observasi juga untuk melihat data lapangaan sebagai bahan analisis kekuatan, kelemahan, ancaman dan tanatangan (SWOT).

Keduametode wawancara yang digunakan untuk menggali data yang tidak tertulis terkait dengan pesantren Daru Ulil Albab, yang terkait dengan tujuan pimpinan unit yayasan dalam mengitegrasikan pondok pesantren, serta tujuan yang dikehendaki stakeholders dan sumbangsihnya dalam pendidikan di pesantren DUA ini. Yang terakhir dokumentasi digubakan untuk menggali data tentang hasil tertulis dan terpampang dalan dokumen terkait dengan kebijakan dan program kerja pesantren DUA untuk mencetak santri berkepribadian tangguh.

\section{Pelaksanaan integrasi pendidikan di Pesantren terpadu Daru Ulil Albab.}

Pelaksanaan integrasi pendidikan di pesantren Daru Ulil Albab dimulai dari penetapan visi, misi dan tujuan. Visi \& Misi. 
Pesantren yang berdiri satu dasawarsa lebih sedikit ini dalam eksistensinya memiliki visi "Menjadi Model Pesantren Masa Depan" dengan empat misi besar, pertama, Membangun Pesantren Terpadu Kontemporer. Kedua, Mengupayakan Revitalisasi Syari'at Islam. Ketiga, Mengoptimalkan Peningkatan Kuwalitas SDM dan Pemberdayaan Umat. Ketiga misi besar tersebut di lingkupi dengan motto "Menjaga Tradisi Lama Yang Masih Relevan dan Melakukan Inovasi yang lebih relevan" 10

Sementara tujua dari pesantren ini adalah meninggikan kalimat Allah dan meratakan rahmat-nya bagi seluruh alam. Harapannya dengan tujuan ini seluruh produk pesantren ini dengan kapasitas dan menekuni profesi apapun akan tetap menjunjung tinggi tujuan di atas dengan tanpa mengabaikan profesionalisme di bidang masing masing ${ }^{11}$.

\section{Pengelolaan dan Pengawasan}

\section{1) Tingkat yayasan.}

Pengelolaan dan pengawasan di tingkat ini dipimpin langsung oleh pembina yayasan dengan melibatkan seluruh pimpinan unit/ lembaga. Kegiatan ini dilakukan pada tanggal 8 setiap bulan yang dikemas dengan istilah kegiatan delapanan. Kontent dalam forum tersebut berisi kegiatan mujahadah dan evaluasi kegiatan yang telah dilakukan, sekaligus mecari solusi berbagai masalah yang akan diambil. Diluar kegiatan delapan ini secara insidentil pembina juga sering mengumpulkan pimpinan unit untuk merespons setiap perkembangan yang terjadi, hal itu sebagaimana yang dilakukan oleh pembina/pengasuh pesantren saat merespont tawaran kerjasama dari dunia usaha kepada SMK Islam Ulul Albab, saat itu pembina langsung memanggil kepala SMKI-UA dan segenap pejabat yayasan untuk menjajaki kemungkinan adanya kerjasama

10 Dokumen Pesantren terpadu Daru Ulil Alba, Profil Pesanten Daru Ulil Albab, (Nganjuk : yayasan pondok pesantren Daru Ulil Alab-YPP DUA, 2005).

11 ibid tersebut $^{12}$

\section{2) Tingkat Unit lembaga.}

Setiap pimpinan unit memiliki tanggung jawab untuk mendorong terlaksananya program-program yang telah direncanakan ditingkat satuan pendidikan yang dipimpinnya. Kegiatan ini dimaksudkan untuk mengevaluasi program kegiatan yang telah dilaksanan sekaligus untuk merespons berbagai masukan, usulah dari bawah, serta untuk memecahkan permasalahan yang terjadi. ${ }^{13}$ Kegiatan seperti ini dilakukan oleh masing-masing unit yayasan setiap seminggu sekali meskipun waktunya tidak dijadwal secara khusus. namun apaila ada hal-hal mendesak, seperti saat terjadi insiden keamanan dan ketertiban, maka pimpinan unit segera mengumpulkan stap-stapnya untuk mencari solusi pemecahannya. ${ }^{14}$

\section{3) Tingkat Siswa/santri}

\section{a) Santri Muqim (Bording)}

Jumlah siswa/santri yang cukup banyak, dan tingkat usia yang beragam mulai dari tingkat RA sampai SLTA, tentu pelayanan pendidikan kepada mereka tidak bisa disamakan, oleh sebab itu agar siswa/santri bisa tuntas dan maksimal dalam mengikuti proses kegiatan tarbiyah, maka di pesantren ini bentuk beberapa orang mushrif yang di singkatt dengan INSAN DUA (ikatan santri Daru Ulil Alab), mereka terdiri dari para ustadz/dzah muda yang tinggal bersama dengan santri/siswa yang sekaligus bertindak sebagai pendamping siswa/santri selama di pesantren. Tugas tugas utama mereka adalah mengadvokasi, dan mengawasi kegiatan santri sehari-hari sesuai dengan tingkat akademik masing masing. Setiap santri berada di bawah asuhan pembina (musyrif). Dan seorang musyrif hanya membina santri maksimal 10 orang siswa-santri. Pembinaan serta pengawasan santri secara umum dilakukan oleh murobbi. Sehingga musyrif bertindak sebagai wakil

12 Observasi di pesantren terpadu Daru Ulil Albab Kelutan pada tanggal 14-17 Mei 2016

13 Wawancara dengan Kharisuddin Aqib, di serambi masjid pesantren terpadu Daru Ulil Albab pada tanggal, 14 Mei 2016 jam 20.15-21.00

14 Ibid 
pengasuh (murobbi). ${ }^{15}$

Dalam pembinaan integral kepribadian, siswa-santri harus mengikuti pengembangan kognesi yang berupa pendidikan pola tutorial dan klasikal, serta diskusi kelompok. Sedangkan untuk pengembangan afeksi santri harus mengikuti kegiatan dzikir, mujahadah dan tartil al-qur'an. Adapun untuk pengembangan psikomotorik santri harus mengikuti praktek ibadah, praktek ketrampilan profesi, Out bond islami, dan penugasan-penugasan oleh musyrif secara disiplin ${ }^{16}$

\section{b) Santri Non Bording (Nduduk).}

Untuk menjaga dan mengarahkan spirit dan motivasi santri/siswa agar tidak keluar dari tujuan utama pendidikan, (Li 'i'laa'i kalimatillah walinasri rahmatihi lil 'alamin), maka pada setiap hari Sabtu pagi, seluruh keluarga besar pesantren terpadu Daru Ulil Albab, mulai dari guru, siswa/santri (muqin dan yang Nduduk) serta seluruh karyawan pada setiap Sabtu pagi mulai jam $06.30 \mathrm{~s} / \mathrm{d}$ 07.30 wib oleh pemina pesantren diberikan kajian tafsir akhlaqi sebagaimana yang sudah dijelaskan diatas ${ }^{17}$.

\section{a. Pengembangan Kelembagaan}

Pesantren terpadu Daru Ulil Albab dari aspek kelembagaan juga memiliki upaya-upaya pengembangan baik yang bersifat akademik, sosial, dan ekonomi. Hal ini dilakukan agar keberadaan lembaga yang dibangun bisa saling bersinergi untuk mewujudkan visi dan misi yayasan,

\section{a. Akademik}

Pada sektor akademik pesantren terpadu Daru Ulil Albab telah melakukan beberapa pengembangan diantaranya adalah penambahan jurusan pada SMK dari hanya Teknik Komputer dan Jaringan (TKJ) dan Multi Media (MM) menjari bertambah pada jurusan Perbankan, dan penegembangan

15 Ibid.

16 Ibid.

17 Ibid. yang terpabu dalam tiga bulan terahir adalah pendirian sekolah kewirusahaan (Madrasatu Tujjar), sekolah ini dibangun untuk mencetak para interprainer yang leaders ship dan leaders yang interprainership. ${ }^{18}$

\section{b. Upaya Sosial}

Upaya sosial yang dilakukan pesantren dalan mendukung pencapaian target integrasi pendidikan adalah melibatkan partisipasi masyarakat dalam penyelenggaraan pendidikan sesuai dengan kapasitas masing-masing, salah satunya adalah mendirikan Pujasera sebagai wadah asosiasi seluruh pedagang kaki lima dan masyarakat pedagang sekitar pesantren. Hal ini dilakukan karena disamping untuk mempermudah pengawasan higienitas dan kesehatan kuliner yang akan dikonsumsi siswa/ santri, juga untuk menambah pendapatan ekonomi masyarakat. Upaya pengembangan sosial lainnya adalah membangun kerjasama dengan tokoh-tokoh masyarakat untuk menjembatani pelaksanaan dakwah keluar (khuruj) bagi siswa/santri yang bertugas keluar pesantren.

\section{c. Upaya Ekonomi}

Sebagaimana dijelaskan oleh pengasuh pesantren, untuk memperkokoh eksistensi pesantren ini, yayasan pesantren telah melakukan berbagai upaya pembangunan ekonomi, salah satunya adalah pendirian Bank Ulul Albab (berafiliasi dengan BNI) yang bisa diakses oleh masyarakat umum, dan yang barubaru ini didirikan adalah UA-Mart, diluar upaya pendirian lembaga ekonomi, pesantren juga telah melakukan investasi di sektor perkebunan kelapa sawit, saat ini lahan yang telah dimiliki yayasan seluas $5 \mathrm{Ha}$, namun karena masih perlu perawatan intensif, maka hasil produksinya dikemalikan untuk perawatan dan pengemangan lahan ${ }^{19}$. Contoh lain dari upaya pesantren ini adalah produksi air mineral dengan merk ABUA (Air Berkah Ulul Alab), usaha ini belum sepenuhnya berhasih karena

\footnotetext{
18 Wawancara dengan Kharisuddin Aqi, di serambi masjid pesantren terpadu Daru Ulil Albab pada tanggal, 16 Mei 2016 jam 20.15-21.00

19 Ibid
} 
terkendala permodalan dan pemasaran, ${ }^{20}$.

\section{d. Pengembangan Sarana prasarana}

Upaya lain yang dilakukan pesantren terpadu Daru Ulil Albab adalah pengembangan sarana prasarana, langkah ini diambil untuk menciptakan performent pesantren sebagai penyelenggara pendidikan yang profesional dan modern. ${ }^{21}$ Upaya ini tidak didasarkan pada target waktu, namun pada tingkat kebutuhan akan sarana prasarana tersebut, misalnya selama ini jumlah peserta didik mengalami peningkatan yang cukup signifikan, maka yayasan merespons hal tersebut dengan mengupayakan penambahan ruang kelas baru, contoh lainnya adalah, selama ini penggunaan perpustakaa masih gabungan antara SMP, SMK dan MA, maka yayasan mengupayakan penambahan perpustakaan untuk masingmasing unit pendidikan ${ }^{22}$.

Sampai saat ini sarana pendukung pendidikan di pesantren ini terus dikembangkan untuk menjawab kebutuhan akan sarana yang representatif. Dalam lima tahun terahir setiap tahun selalu didakan penambahan sarana, seperti penambahan ruang kelas, pembangunan gedung perpustakaan dan isinya, laboratorium IPA, asrama hunian santri, pembangunan asrama yatim piatu (Baitul Yatama) dan pagar pesantren lain-lain ${ }^{23}$.

\section{Integrasi Sarana prasarana}

Teori integrasi pendidikan di pesantren terpadu Daru Ulil Albab dari aspek sarpras, adalah dengan cara mengatur berbagai kegiatan secara tersentral dalam beberapa sarana, seperti kegiatan ubudiah di masjid, olah raga dan apel (lapangan/ hall/gor), koordinasi dan konsolidasi di rumah/kediaman pengasuh. intinya untuk mengintegrasikan pendidikan secara makro, semua siswa/santri dalam berbagai latar belakang sekolah disatukan pada

20 Oservasi di pesantren terpadu Daru Ulil Albab pada tanggal 16-19 April 2016 Jam 13.00

21 Wawancara dengan Zainuddin, di Baitul Yatama pesantren terpadu Daru Ulil Albab pada tanggal, $17 \mathrm{Mei}$ 2016 jam 20.15-21.00

\section{2 ibid}

23 Oservasi di pesantren terpadu Daru Ulil Albab pada tanggal 16-19 April 2016 Jam 13.00 sarana-sarana tersebut, dan menerima kontent pendidikan yang sama, seperti internalisasi nilai grapiyak, pembiasaan dzikir, olah raga, dan lain sebagainya.

Pandangan penulis terkait dengan teori ini adalah sependapat, alasannya karena dengan teori seperti ini semua siswa/santri akan lebih mudah diarahkan, dimotivasi dan dipengaruhi secara educativ kearah pencapaian tujuan yayasan.

\section{Integrasi kelembagaan}

Secara kelembagaan peantren terpadu Daru Ulil Albab, terdapat dalam satu lembaga dengan satu direktur dan berada di bawah satu yayasan, yaitu; Yayasan Pondok Pesantren Daru Ulil Albab.

Konsep seperti ini memiliki sisi positif dan sisi negatif. Alasannya karena; Pertama, keberadaan yayasan/pesantren lebih kuat karena memiliki otoritas yang lebih besar. Kedua, kesenjangan biaya operasional sub unit bisa di pecahkan dengan cara subsidi silang. Ketiga, internalisasi program pesantren lebih mudah. Keempat, potensi anggota lebih mudah terekplorasi.

Sementara sisi negatifnya adalah; Pertama, lebih mudah terjadi perpecahan apabila perlakuan terhadap unit kurang adil. Kedua, berpotensi terjadinya rivalitas yang tidak sehat antara unit karena kemungkinan adanya perbedaan beban dan kompensasi finansial. Ketiga, akan mudah terjadi kegoncangan apabila pemegang tampuk pimpinan tertinggi tidak memiliki kapasitas yang cukup,

\section{Integrasi Kurikulum}

Sebagaimana yang dijelaskan oleh Cohen dan Manion (1992) dan Brand (1991) yang telah dipaparkan di bab II, bahwa pelaksanaan integrasi pendidikan itu memiliki beberapa variasi berkenaan dengan pendidikan yang dilaksanakan dalam suasana pendidikan progresif yaitu kurikulum terpadu (integrated curriculum), hari terpadu (integrated day), dan pembelajaran terpadu (integrated learning). Dari pendapat ketiga pakar diatas, penerapan 
yang paling bisa mewadahi terhadap kesemua variasi pendidikan integrasi adalah model pendidikan yang berbasis pesantren terpadu. Hal itu karena pesantren terpadu memiliki banyak unsur pendukung, seperti sarana ibadah, sarana sekolah, asrama santri dan kegiatan terstruktur selama 24 jam.

Sementara integrasi pendidikan di pesantren Daru Ulil Alab meliputi ketiga variasi diatas sekaligus, yaitu kurikulum terpadu (integrated curriculum), hari terpadu (integrated day), dan pembelajaran terpadu (integrated learning). Teknis implementasi kurikulum di pesantren ini dilakukan dengan dua cara. Pertama, di setiap unit pendidikan formal baik SMP, SMK, MA atau unit pendidikan lain yang berada diawah naungan pesantren ini secara profesional melaksanakan kurikulum sesuai struktur kurikulum pemerintah baik yang berada diawah binaan kementrian pendidikan atau kementrian agama. Kedua, implementasi kurikulum formal tersebut di optimalisasikan dengan penerapan grand kurikulum Grapiyak secara terpadu/terintgrasi yang diberlakukan untuk seluruh keluarga besar pesantren, mulai dari siswa/santri, guru, karyawan dan bahkan para pedagang yang berada di lingkungan pesantren Daru Ulil Albab.

\section{Integrasi Manajemen}

Bentuk integrasi menejemen yang dikembangkan di pesantren ini dengan cara menggabungkan seluruh manajerial lembaga yang ada dibawah naungan yayasan pesantren Daru Ulil Albab pada manajemen adminitrasi akademik, manajemen keuangan, manajemen ketenagaan dan kesiswaan ${ }^{24}$.

Konsep seperti ini pada satu sisi memiliki banyak kelebihan, namun pada sisi lain juga memiliki kelemahan. Kelebihan teori ini adalah; Pertama, departemen lebih ramping dan koordinasi lebih mudah. Kedua, sistem kontrol lebih efektif. Ketiga, sistem birokrasi lebih efisien. Sedang kelemahan teori ini adalah; Pertama, proses pelayanan sering molor karena pintu layanan terbatas. Kedua,

24 Wawancara dengan Kharisuddin Aqib, di serambi masjid pesantren terpadu Daru Ulil Albab pada tanggal, 14 Mei 2016 jam 20.15-21.00 proses pembiayaan program unit kurang simple, sehingga sering molor.

\section{Integrasi Tradisi}

Bentuk integrasi tradisi di pesantren ini adalah dengan cara mebudayakan tradisi timur (yang tawasuth, tawazun, dan tasamuh,) dan tradisi Barat (yang rasional, kritis, produktif). Gambaran singkatnya adalah di pesantren ini semua siswa/santri di dorong untuk terbiasa dengan berbagai kegiatan yang mencerminkan tradisi masyarakat ketimuran, seperti gemar berdzikir, (baca qur'an, tahlil, wirid, ziarah kubur dll), toleran, peka dan tanggap terhadap perkembangan sosial, ramah dan peduli. Di sisi lain mereka juga aplikatif, rasional, kritis, produktif yang menjadi cerminan tradisi Barat, untuk itu mereka di bekali disiplin ilmu modern yang mengarahkan pada pematangan kecakapan vokasional, sains dan teknologi disamping juga ilmu-ilmu agama.

Secara konsep teori ini memang bagus, namun konsekwensi dari penerapan teori ini cukup banyak, diantaranya; Pertama, siswa/ santri harus isolir dari budaya yang tidak mendukung program tersebut, dalam hal ini bisa berbentuk asrama atau rumah kost. Kedua, seluruh intrumen pembentukan tradisi harus dipersiapkan dengan baik, seperti SDM pendukung yang memadahi, sumberdaya lingkungan/alam, dan adanya komitmen bersama. Ketiga, seluruh kebutuhan sarana pendukung program hrus terpenuhi.

Berdasarkan aspek diatas, menurut penulis pesantren terpadu Daru Ulil Albab ini memiliki peluang untuk mewujudkan hal tersebut, namun masih membutuhkan perjuangan yang panjang.

\section{Kesimpulan}

Berdasarkan analisis yang telah dilakukan oleh penulis, maka dapat diambil kesimpulan sebagai berikut; 1) Pekalsanaan integrasi pendidikan di pesantren terpadu Daru Ulil Albab ini. Penerapan konsep integrasi pendidikan di pesantren ini dengan cara memadukan lima unsur pendidikan. Pertama keterpaduan sarana prasarana. Kedua. keterpaduan kelembagaan. 
Ketiga, keterpaduan kurikulum. Keempat, keterpaduan manajemen. Kelima, Keterpaduan budaya. pola integrasi berbeda dengan pola integrasi pendidikan pada umumnya. 2) Target yang ingin di capai oleh pesantren terpadu Daru Ulil Albab, Pertama memiliki mutu bisa menjadi pribadi-pribadi yang ulul Albab, baik badannya, baik akalnya, dan baik hatinya (Sehat hahir dan Bathin). Kedua, memiliki sistem manajerial yang baik solid dan kuat. Ketiga memiliki sarana pendidikan yang memadahi dan lembaga unit yang variatif. 2) Sedang upaya yang dilakukan pesantren terpadu Daru Ulil Albab untuk mencapai target yang telah dicanangkan tersebut adalah dengan cara; Pertama, optimalisasi kegiatan. Kedua, optimalisasi pengeloaan dan pengawasan. Ketiga, pengembangan kelembagaan. Keempat, pengembangan sarana prasarana.

\section{DAFTAR PUSTAKA}

Amalia Sunaryo Dian, Konsep-konsep kepribadian. (online) http://amaliasunaryo.blogspot.co.id/2013/04/ konsep-kepribadian-dan-polaperilaku.html. diakses 28/09/2016

Arifin Zainal, Pengembangan Managemen Mutu Kurikulum Pendidikan Islam, DIVA Press cet.1 (Yogyakarta: 2012,)

Bagus Denny. Devinisi Sikap dan Kepribadian (online) http://jurnal-sdm.blogspot. co.id/2011/11/sikap-dan-kepribadianpengertian-sikap.html

Bahri M. Ghazali.(2011) Pendidikan Pesantren Berwawasan Lingkungan. Jakarta; Pedoman Ilmu

Basrowi dan Suwandi.(2008) Memahami Penelitian Kualitatif. Jakarta; Rineka Cipta.

Bruce Jaoyce-Marsha Weil-Emily Calhoun,( 2009) Models Of Teaching, Yogyakarta; Pustaka Pelajar

Dryden Gordong dan Vos Jeanette, (2000) Revolosi cara Belajar, Bandung Kaifa PT. Mizan Pustaka.

Elsiana "Pengertian Kepribadian, Ciri-Ciri,
Unsur, Jenis \& Definisi Para Ahli" (on line) http://www.artikelsiana. com/2015/07/. Diakses 16 Mei 2017

Engking Soewarman Hasan. (2011) Landasan Filosofis Pengembangan Pendidikan Terpadu Pesantren. Mimbar Pendidikan No. 4/XX/2001

Ensiklopedi Wikipedia, Makna Integrasi,(on line) http://id.wikipedia. org/ wiki/ Integrasi_sosial, diakses 16 Mei 2017

Ensiklopedi Wikipedia. (2016) Makna Integrasi. (online) http://id.wikipedia. org/ wiki/Integrasi_sosial,

Fatimaningsih, Nur Inayah Endry, 2009 "Sistem Pendidikan Formal Di Pondok Pesantren", Jurnal Sociologie, Vol. 1, No. 3: 214-223

Hepata Jaya, 10 model pembelajaran sains terpadu (robin fogarty, 1991) (online) http://heptajayawardana.blogspot. co.id/2012/10/10-model-pembela jaran-sains-terpadu.html diakses, $10 \mathrm{Mei}$ 2017

Idris Usman Muh.(2013) Pesantren Sebagai Lembaga Pendidikan Islam. Jurnal Al Hikmah Vol. XIV Nomor 1/2013

Integrasi Sistem Pendidikan di Pondok Pesantren, (on Line) http://artikelsmkdarunnajah.blogspot.co.id/2012/03/ integrasi-sistem-pendidikan-dipondok.html

Jamaluddin M.(2012). Metamorfosis Pesantren Di Era Globalisasi, KARSA, Vol. 20 No. 1 Tahun 2012

Kholil Anwar "Pengertian Pembelajaran Terpadu" (on line) http://anwarholil. blogspot.co.id/2008/04/pengertianpembelajaran-terpadu.html

Madjid N.(1997) Bilik-Bilik Pesantren Sebuah Potret Perjalanan Jakarta: Paramadina, 1997

Mastuhu, (1994) Dinamika sistem pendidikan pesantren. Jakarta: INIS.

Moesa A.M. (2015) Pendidkan islam di era global. Seminar Pendidikan Agama Islam, IAIT, Kediri, tanggal 6 Juni 
2015.

Moleong Lexy J.(2006) Metodologi Penelitian Kualitatif Edisi Revisi.Bandung: PT. Remaja Rosdakarya Offset

Muhaimin, dkk, (2001) Paradigma Pendidikan Islam: Upaya mengefektifkan Pendidikan Agama Islam di Sekolah, Jakarta: Remaja Rosdakarya, cet.1.k Judul Buku/Artikel titik penerbit

Muhibbin, (2004) Psikologi Pendidikan dengan Pendekatan Terpadu, Bandung: Remaja Rosdakarya.

Nata Abuddin, dkk. 2002. Integrasi Ilmu Agama dan Ilmu Umum. Jakarta. Raja Grafindo Persada

Nugroho Budi.(2013) Triangulasi pada Penelitian Kualitatif. http://www.pdii. lipi.go.id/read, 4 April 2013

Nuh Muhammad, Disain Induk Pendidikan Karakter. Kemendiknas Jakarta, (Online)http://pendikar.dikti. go.id/gdp/wp-content/uploads/ Desain-Induk-Pendidikan-Karakter Kemdiknas.pdf

Qomar Mujammil,( 2003), Pesantren Dari Trnsformasi Metodologi Menuju Demokratisasi Institusi. Jakartahal; Erlangga.

Qomar, Mujamil, (2007) Manajemen Pendidikan Islam, Malang:Erlangga, 2007

R. Sudarsono.(1995) Kenakalan remaja. Jakarta; Rineka Cipta.

Razaq Hagfizduddin" Definisi dan Makna Santri", (online) https:// hafizhuddin30. wordpress.com/tag/ definisi-santri/ diakses tanggal 14 Mei 2017

Sabda, Syaifuddin. (2006) Model Kurikulum Terpadu IPTEK \& IMTAQ. Jakarta: Quantum Teaching

Salim \& Syahrum, (20120) Metodologi Penelitian Kualitatif, Bandung: Citapustaka Media.
Saputro Ryo Bambang.(2013) "Triangulasi dalam Penelitian Kualitatif”. (onlina) http://phisiceducation09.blogspot. com,

Satori, D., (2002), Implementasi Life Skills dalam Konteks Pendidikan di Sekolah, Journal Pendidikan dan Kebudayaan

Siti Sholiha Salma, Kepribadian dalam pandangan Islam, (online)http:// salma- finzana.blogspot.co.id/2013/12/ kepribadian-dalam-pandangan islam. html 14 Desember 2013.

Steenbrink Karel A, (1974) Pesantren, Madrasah dan Sekolah. Jakarta: LP3ES. Syah,

Sudarso Deding " Lembaga Pendidikan Islam Terpadu" (online) http://dedingsudarso.blogspot.co.id/2010/04/ lembaga-pendidikan-islam-terpadu. html

Suharsimi Arikunto.(2002).Prosedur Penelitian Suatu Pendekatan Praktek. Jakarta: PT Rineka Cipta.

Syaehotin Sayyidah, "Pengembangan Pendidikan Pesantren Terpadu" (online) file:///C:/Users/pc/Downloads/5331527-1-SM\%20(2).pdf

Tahap-tahap Pembentukan Kepribadian, (online) http://www.ilmusocial. com/ tahap-tahap-pembentukankepribadian/ 21 Januari 2015,

Undang-Undang No 20 tahun 2003 tentang Sisdiknas (2010), Bandung Nuansa Aulia.

Widyaiswara Muda Harli Trisdiono, Pembelajaran Terpadu Pada Sekolah Dasar http://lpmpjogja.org/ pembelajaran-terpadu-pada-sekolahdasar 